\title{
Prototipe Mesin Penetas Telor Otomatis Berbasis Mikrokontroler Atmega328 menggunakan Sensor DHT11
}

\author{
${ }^{1)}$ Tia Astiyah Hasan, ${ }^{2)}$ Jamaludin indra, ${ }^{3)}$ Garno \\ ${ }^{123}$ Universitas Buana Perjuangan Karawang \\ Tia.Astiya@ubpkarawang.ac.id, Jamaludin.indra82@gmail.com, muhammadgarno@gmail.com \\ Jl. HS.Ronggo Waluyo, Telukjambe Timur, Karawang, Jawa Barat 41361
}

\begin{abstract}
ABSTRAK
Mikrokontroler ATMEA328 yang terhubung dengan sensor DHT11 untuk mesin penetas telor otomatis. Tempertur dan kelembaban merupakan dua faktor utama selain sirkulasi udara dan pemutaran posisi telur yang menetukan keberhasilan penetasan telur, namun mesin tetas telur sederhana yang ada dipasaran hanya memperhitungkan faktor temperatur saja yang menggunakan kontrol mekanik biasa. Pengujian dilakukan dengan metode eksperimen dengan melakukan uji coba langsung dari mesin penetas telor yang dibuat yaitu dengan meletakan beberapa telor untuk di kondisikan dalam mesin pengujian dengan suhu dalam inkubator dan pengecekan selama dua jam pertama dengan interval pengecekan 10 menit dengan teknik pemutaran secara otomatis dengan bantuan motor servo dengan tegangan 5 Volt dengan torsi $10 \mathrm{Kg} / \mathrm{cm}$ untuk memindahkan posisi rak dalam inkubator agar terjadi sudut $18^{\circ}$ untuk tiap-tiap kondisi yang ditentukan secara berkasinambungan dan bergantian sudutnya. DHT11 mampu mendeteksi suhu dan kelembaban dalam inkubator, temperatur optimal penetasan telur $38^{\circ}-40^{\circ} \mathrm{C}$ atau tergantung jenis telur yang ditetaskan dan kelembaban optimal 52\% - 55\% RH, dan servo mampu bergerak untuk menggerakan rak telur sesuai waktu.
\end{abstract}

Kata kunci; Atmega328, Tempertur, Kelembaban, Mikrokontroler, Inkubator

\section{PENDAHULUAN}

Seiring perkembangan dan pertumbuhan penduduk yang kian cepat di dunia khususnya di Indonesia maka berdampak pada meningkatnya konsumsi masyarakat, khususnya akan kebutuhan daging unggas maupun telurnya yang kaya akan sumber protein utama, maka harus dimbangi dengan persediaan yang cukup untuk memenuhi ketersediaan pangan yang mengandung protein yang tinggi tetap terpenuhi. Salah satu caranya adalah dengan mengganti mesin penetas telur sederhana dengan masin penetas telur yang otomatis sehingga dalam proses penetasan telur relatif menjadi lebih mudah dan praktis dengan hasil penetasan lebih baik.

Perancangan dan pembuatan suatu sistem monitoring temperetur dan kelembaban suatu ruangan (egg incubator) yang otomatis dengan menggunakan modul DHT11. Sistem sensor yang digunakan berbasis pada sifat polymer kapasitif untuk sensor kelembaban dan band gap untuk sensor temperatur. Seluruh pengontrolan dilkukan oleh Atmega328.

Seluruh aktifitas dari sistem tersebut dikontrol secara On-Off sudah bisa dianggap cukup untuk mengontrol suatu mesin penetas telur secara otomatis oleh mikrokontroler. Penggunaan kontroler tersebut diharapkan bisa didapatkan pengontrolan suhu dan kelembaban yang diinginkan sehingga dapat menetaskan telur menjad bibit unggas yang berkualitas baik.

\section{METODE PENELITIAN}

A. Flowchart Sistem

Metode penelitian dari mesin otomatis penetas telor ini akan mengikuti Flowchart mesin penetas telur otomatis yang dirancang sebagai berikut; 


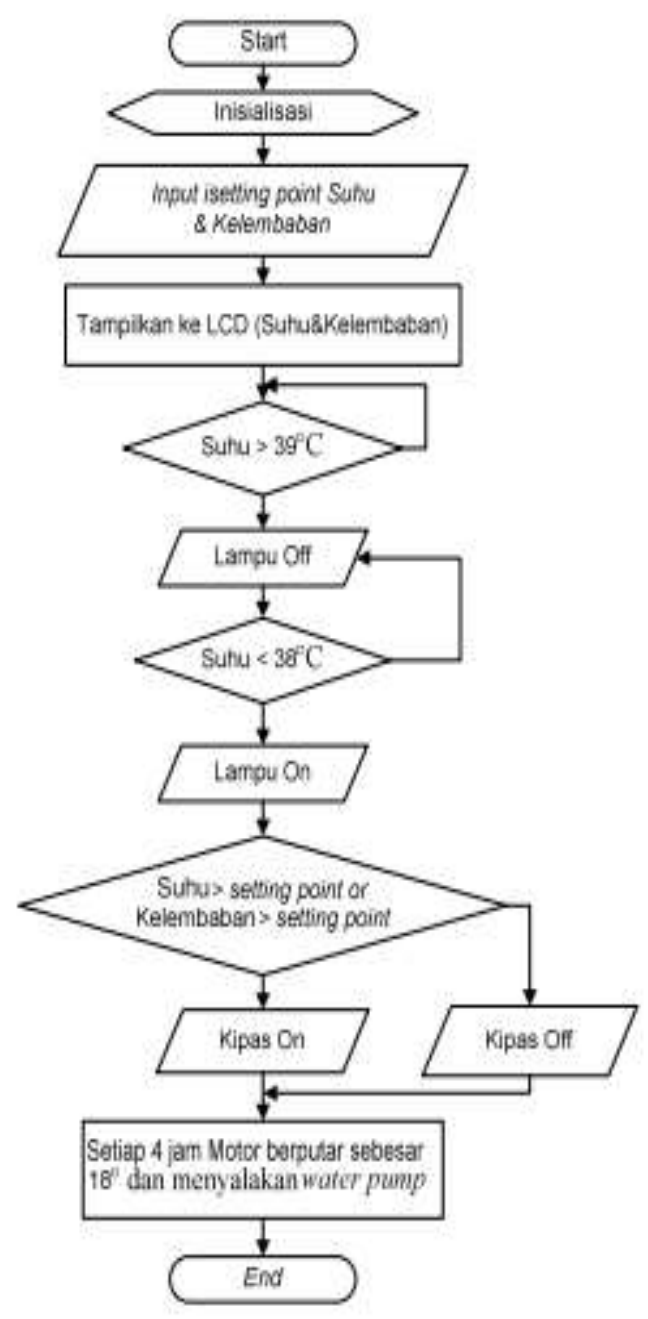

Gambar 1 Flowchart Sistem Secara Keseluruhan

Flowchart yang dirancang seperti gambar 1 untuk dapat di implementasikan perlu adanya langkah yang harus di persiapkan diantaranya

B. Perancangan Hardware

Sistem utama pada mesin penetas telur otomatis ini diatur oleh mikrokontroler. Input mikrokontroler ini diperoleh dari sensor SHT 11 untuk mendapatkan nilai suhu dan kelembaban. Data dari sensor tersebut akan ditampilkan nilainya pada LCD. Ketika suhu terlalu tinggi, maka kipas akan menyala dan lampu akan mati, sedangkan jika suhu lebih rendah dari set point maka lampu menyala kembali dan kipas akan mati. Disamping itu Water Pump akan menyemprotkan air ke busa/spons jika nilai kelembabannya lebih rendah.

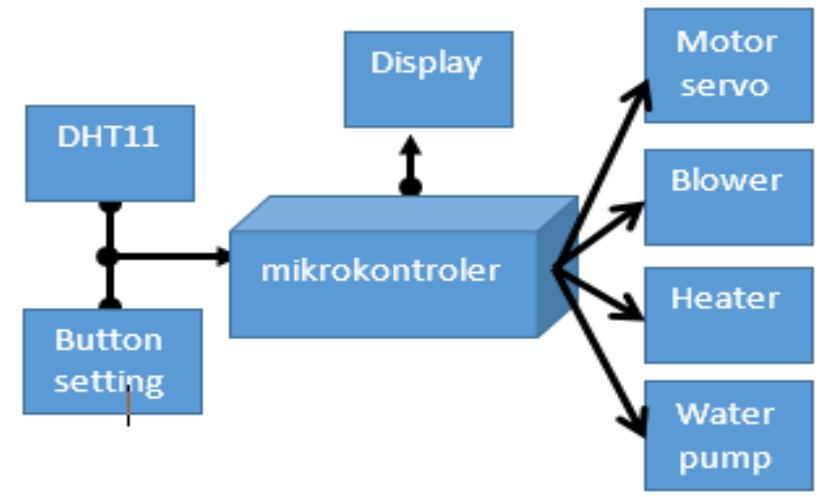

Gambar 2 Perancangan Hardware 
dari set point untuk menjaga kelembaban telur agar telur tidak kering dan keras karena bisa menghambat dalam penetasan telur ayam. Jika kelembaban terlalu tinggi, maka kipas akan menyala untuk menurunkan tingkat kelembaban dan kipas akan mati jika kelembaban sudah normal kembali.

C. Arduino Uno

Arduino uno mikrokontroler berbasis Atmega328 (datasheet), mamiliki 14 digital input/output pin (6 pin digunakan sebagai output PWM) dan 6 input analog. $16 \mathrm{Mhz}$ osilator kristal, koneksi USB, jack listrik, header ICSP dan tombol reset diperlukan untuk mendukung mikrokontroler, catu daya bisa menggunakan langsung dari USB, adaptor AC-DC atau baterai[2]. Sedangkan koneksi arduino uno dengan perangkat penunjang dapat dilihat dari gambar 3

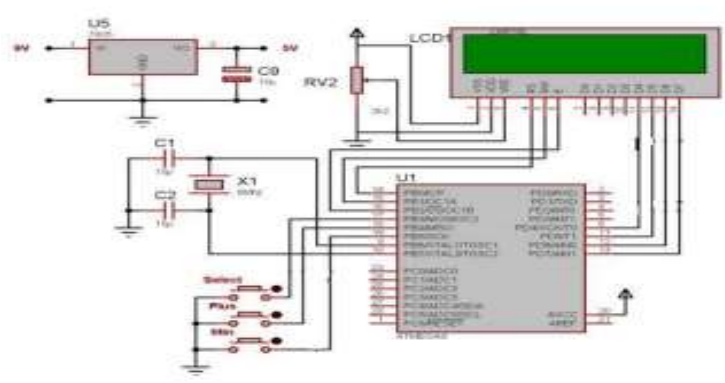

Gambar 3 Rangkaian Atmega328 dengan rangkaian pendukung

D. Motor Servo.

Pemutaran secara otomatis dengan bantuan motor servo dengan tegangan 5 Volt dengan torsi $10 \mathrm{Kg} / \mathrm{cm}$ untuk memindahkan posisi rak dalam inkubator agar terjadi sudut $18^{\circ}$ untuk tiap-tiap kondisi yang ditentukan secara berkasinambungan dan bergantian sudutnya. Pemutaran telur sedikitnya adalah 3 kali dalam 24 jam, untuk mencegah embrio telur melekat pada selaput membran bagian telur, akan tetapi dalam mesin ini akan bergerak sesuai kondisi suhu dalam inkubator.

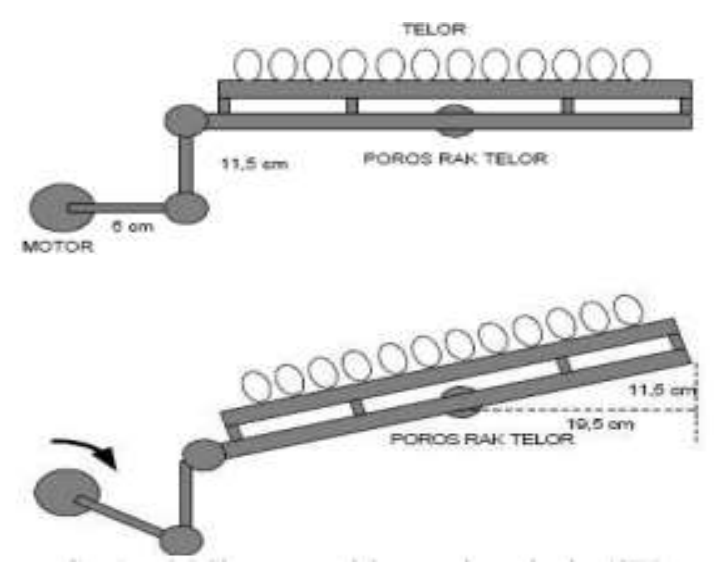

Gambar 4 Gerak motor servo terhadap rak telur

E. LCD 2X16 karakter

Penggunaan LCD difungsikan unruk menampilkan kondisi temperatur, kelembaban dan waktu dari pertama mesin penetas telur dinyalakan. Pada sistem modul ini digunakan LCD 2X16.

Pada rangkaian LCD 2X16 ditambahkan RP 10k yang berfungsi untuk mengatur ketajaman tampilan layar dan dipasang R 47k, Q9013 pada arus ground.

F. Rangkaian Tombol Masukan

Tombol masukan yang digunakan jenis push button yang menggunakan konsep pembagi tegangan. Rangkaian pembagi tegangan yang dihubungkan ke AD5 (masukan analog ke-lima) dari board arduino. 


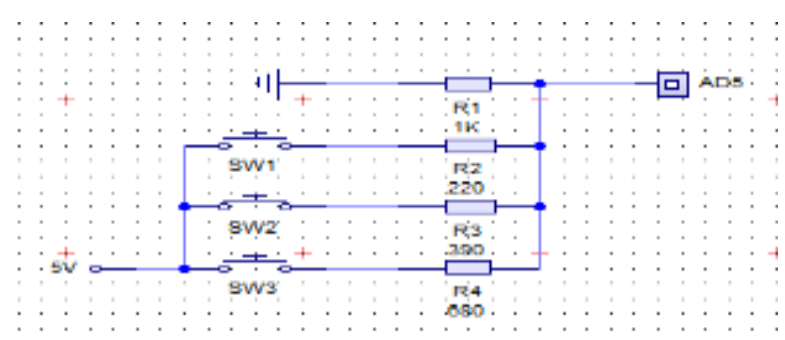

Gambar 5 Rangkaian Tombol Masukan

Dalam rangkaian tombol masukan menggunakan empat buah resistor dengan berbeda nilai tahanan dimana dari perbedaan nilai tahanan tersebut akan dibaca oleh board arduino, sehingga akan menjadi perintah pada pin analog.

G. Rangkaian Driver Kontrol Blower

Rangkaian menggunakan transistor sebagai saklar dari mikrokontroler yang dihubungkan pada port D13 dan relay 12 Volt yang dihubungkan ke kipas. Kipas yang digunakan adalah kipas 12 volt DC berjumlah 2 buah yang diletakan dalam inkubator.

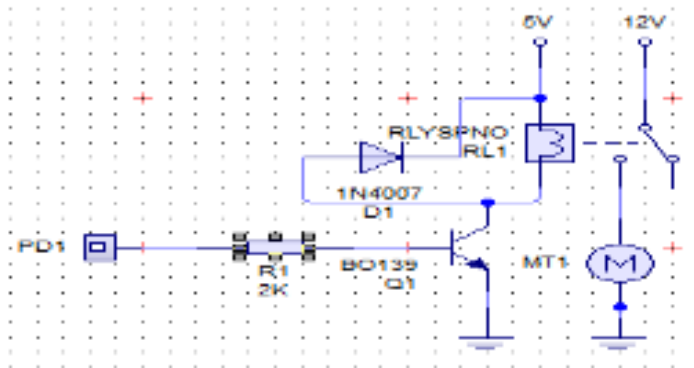

Gambar 6 Rangkaian Driver Blower

Komponen yang dipakai dalam rangkaian driver kipas yaitu resistor $2 \mathrm{k} 2$ yang berfungsi menahan arus jika terjadi hubungan arus pendek dalam driver blower, transistor BO139 sebagai saklar tegangan 5 Volt, dioda 1N4007 dan relay RLY-SPNO sebagai saklar yang diatur secara otomatis oleh mikrokontroler.

\section{H. Rangkaian Driver Kontrol Pemanas}

Rangkaian driver kontrol pemanas masih menggunakan transistor sebagai saklar dari mikrokontroler yang dihubugkan pada port arduino dal relay 12 Volt yang dihubungkan ke lampu pijar sebagai pemanas inkubator.

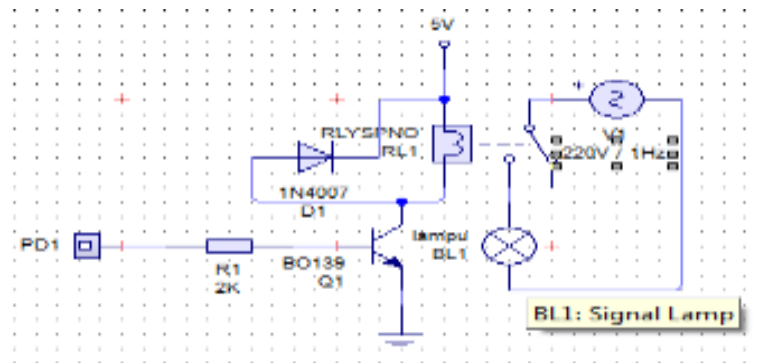

Gambar 7 Rangkaian Driver Pemanas

Suhu standar dalam inkubator tipe forced air (dengan sirkulasi udara) adalah $100^{\circ} \mathrm{F}-102^{\circ} \mathrm{F}$.

Untuk pemanas inkubator menggunakan 4 buah lampu pijar dengan total daya 60 watt dengan masing-masing lampu berdaya 15 watt yang dimaksudkan agar keadaan temperatur dalam inkubator bersifat homogen (merata) sehingga pemanasan telur akan sama rata pada semua daerah.

Komponen yang dipakai dalam rangkaian driver kipas yaitu resistor $2 \mathrm{k} 2$ yang berfungsi menahan arus jika terjadi hubungan arus pendek dalam driver pemanas, transistor BO139 sebagai saklar tegangan 5 Volt, dioda 1N4007 dan relay RLY-SPNO sebagai saklar yang diatur secara otomatis oleh mikrokontroler.

\section{Rangkaian Driver Kontrol Pompa air}

Rangkaian driver kontrol pompa air masih menggunakan transistor sebagai saklar dari mikrokontroler yang dihubugkan pada port arduino dal relay 12 Volt yang dihubungkan ke pompa air sebagai pengatur kelembaban inkubator. 


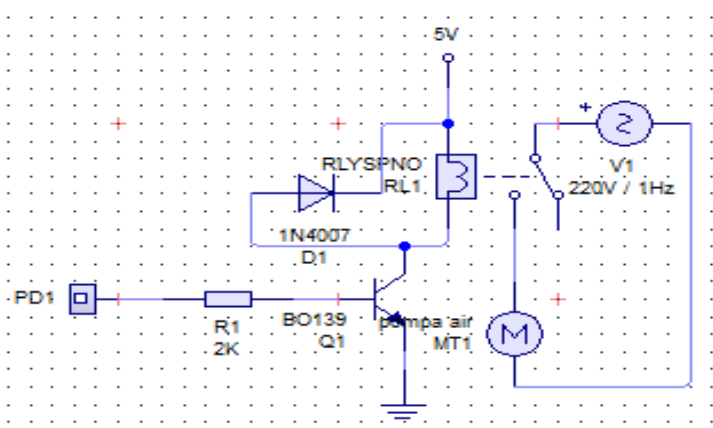

Gambar 8 Rangkaian Driver Pompa Air

Komponen yang dipakai dalam rangkaian driver kipas yaitu resistor $2 \mathrm{k} 2$ yang berfungsi menahan arus jika terjadi hubungan arus pendek dalam driver pompa air, transistor BO139 sebagai saklar tegangan 5 Volt, dioda 1N4007 dan relay RLY-SPNO sebagai saklar yang diatur secara otomatis oleh mikrokontroler.

\section{J. Sensor DHT11}

DHT11 dapat mengukur suhu antara $0-50^{\circ} \mathrm{C}$ dan kelembaban antara 20-90\% dengan resolusi masing-masing sebesar $0,1^{\circ} \mathrm{C}$ dan $1 \% \mathrm{RH}$ (Relative Humidity). Akurasi untuk pengukuran suhu dan kelembaban adalah $(-/+) 2^{\circ} \mathrm{C}$ dan (-/+) $4 \%$ RH.

\section{PEMBAHASAN}

A. Kondisi Mesin Penetas Telur

Pengujian suhu dalam inkubator dengan pengecekan selama dua jam pertama dengan interval pengecekan 10 menit.

Tabel Hasil Pengujian Sensor DHT11 pada Inkubator

\begin{tabular}{|c|c|c|c|c|c|}
\hline paxte & Poirtip & $\begin{array}{l}\text { IFThoes } \\
\text { Dows }\end{array}$ & 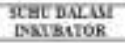 & 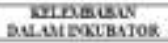 & ExR:40) 5 TER \\
\hline 4 & 4 & w4 & 71 & $n$ & $\pi$ \\
\hline 10 & A1 & 36 & 31 & 5 & It \\
\hline 20 & 4 & if & 24 & 61 & is \\
\hline 30 & AI & 3* & 35 & 61 & H \\
\hline 40 & 4 & If & 35 & 62 & ss \\
\hline 10 & $4 i$ & If & it & a & 进 \\
\hline 6 & $4 !$ & 3 & it & 62 & 19 \\
\hline 50 & 4 & 36 & 34 & 69 & 37 \\
\hline 10 & $4 i$ & if & us & 01 & is \\
\hline$\infty 0$ & At & It & it: & es & II \\
\hline 193 & $4 \mathrm{E}$ & $3 t$ & 34 & 64 & 18 \\
\hline 111 & 4 & 36 & 酐 & 62 & 39 \\
\hline 128 & 4t: & 36 & ye & क & 38 \\
\hline
\end{tabular}

Data pada tabel pengujian sensor DHT11 pada inkubator dapat digambarkan dengan grafik sebagai berikut;

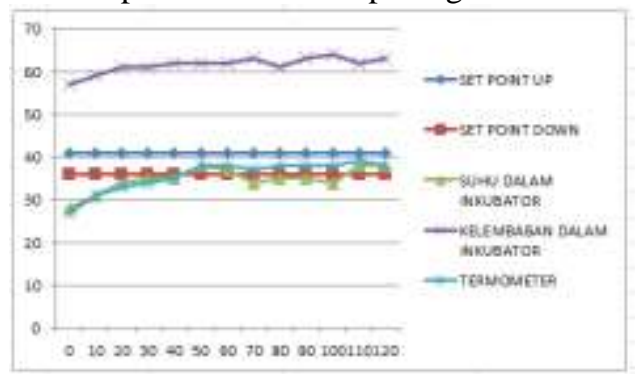

Gambar 4.1 Chart pembacaan sensor DHT11 dalam inkubator 
Pengujian yang dilakukan diatas menggunakan kotak inkubator dengan volume $252000 \mathrm{~cm}^{3}$. Yaitu dengan panjang $70 \mathrm{~cm}$, lebar $60 \mathrm{~cm}$ dan tinggi $60 \mathrm{~cm}$ dengan menggunakan triplex standar tebal $2 \mathrm{~mm}$, dengan jumlah lapisan 2 lapis jarak rongga $2 \mathrm{~cm}$ suhu dalam inkubator relatif stabil sesuai suhu yang diinginkan.

B. Gerak Rak Telur

Gerakan rak telur menggunakan motor servo bergerak dengan interval 4 jam dengan jumlah gerakan tiga kali balikan, gerakan rak telur sudah sesuai dengan yang diharapkan.

C. Lampu pemanas dan kipas

Lampu pemanas dan kipas mengacu pada kondisi suhu dalam inkubator dan setting point. Setelah melakukan pengujian dengan setting point suhu maksimal $41^{\circ} \mathrm{C}$ dan suhu minimal $36^{\circ} \mathrm{C}$, ketika suhu dalam inkubator mencapai suhu diatas atau sama dengan setting point maksimal maka lampu pemanas mati, kipas menyala dan sebaliknya ketika suhu dibawah atau sama dengan setting point minimal lampu pemanas menyala, kipas mati. Dengan demikian lampu pemanas dan kipas telah sesuai dengan yang diharapkan.

D. Pompa air

Pompa air menyala ketika kelembaban didalam inkubator dibawah setting point kelembaban dan sebaliknya pompa air mati ketika kelembaban dalam inkubator di atas atau sama dengan setting point kelembaban maksimal. Dengsn demikisn pomps air telah sesuai dengan yang diharapkan.

E. Pengujian Secara Keseluruhan

Pengujian sistem secara keseluruhan ini dilakukan dengan menggabungkan semua peralatan ke dalam sebuah sistem yang terintegrasi. Tujuannya untuk mengetahui bahwa rangkaian yang dirancang telah bekerja sesuai yang diharapkan. Dari hasil pengujian selama proses dari awal pengujian ternyata kondisi peralatan masih tetap normal dan tidak terjadi gangguan yang berarti, sehingga mesin penetas telur ini sudah siap untuk diaplikasikan dalam kondisi yang sesungguhnya dalam penetasan secara otomatis yang diharapakan.

\section{KESIMPULAN}

Setelah melakukan analisis, perancangan, dan pengujian maka dapat diperoleh kesimpulan sebagai berikut.

1) Sensor suhu DHT11 mampu mendeteksi suhu dan kelembaban dalam inkubator dengan baik.

2) Servo mampu bergerak untuk menggerakan rak telur sesuai waktu yang telah ditentukan

3) Perangkat pemanas, kipas dan pompa air bekerja dengan baik sesuai dengan harapan.

\section{DAFTAR PUSTAKA}

Erwin Fadhila, "Pengendalian Suhu Berbasis Mikrokontroler pada Ruang Penetas Telur", Jurnal Reka Elkomnika, 2337-439X Oktober 2014

Maratur Gabe Simanjutak, "Perancangan Prototype Smart Building Berbasis Arduino UNO”, Singuda Ensikom, Vol 2, No 2, Mei 2013.

Paimin, farry B, 2010. Membuat dan Mengelola Mesin Tetas. Penebar Swadaya. Jakarta.

Rausan Fikri, "Rancang Bangun SistemMonitoring Ketinggian Permukaan Air Menggunakan Mikrokomtroler ATMEGA328P Berbasis Web Service”, Positron, Vol V, No 2, ISSN 2301-4970, 2015.

Slamet Riyadi, "Pembuatan Pintu Geser Otomatis pada Unit Pelayanan Teknis Rumah Pintar Kabupaten Pacitan", Indonesian Journal on Networking Security-Volume 3 No 2-2014.

Taufik Ismailar,'Perancangan dan Realisasi Alat Penetas Telor dengan Catu Daya Pembangkit Listrik Tenaga Surya Berbasis Arduino Uno R3”, Jurnal Reka Elkomika 2337-439X Vol3 No 1, januari 2015, ITENAS. 